\title{
Комп'ютерно-оріснтована математична модель оцінки ефективності тарифної системи оплати за спожиту електроенергію залізницею
}

Проведено аналіз споживання електричної енергї на тягу залізниці для оцінки ефективності застосування диференційованих тарифів через застосування математичної моделі. Запропоновано використовувати математичну модель для визначення ефективності застосування диференційованих тарифів оплати електроенергї.

Ключові слова: модель, електроспоживання, комп'ютерна система комериійного обліку, інформаційні технології, мінімізація оплати електроспоживання, вартість.

\begin{abstract}
Постановка проблеми
На сьогоднішній день залізниці закуповують електроенергію для власних потреб та для постачання своїм абонентам у різних типів постачальників за регульованими та за нерегульованими тарифами [1].

Використання автоматизованої системи комерційного обліку електричної енергії дає змогу отримати картину енергоспоживання кожного об'єкта в режимі, максимально наближеному до реального часу, i відповідно планувати підключення своїх об'єктів 3 максимальною ефективністю. При наявності сучасної комп'ютерної системи комерційного обліку залізниця повністю контролює весь процес електроспоживання і має можливість за погодженням iз постачальниками електричної енергії гнучко переходити до різних тарифних систем, мінімізуючи свої витрати. За цих умов об'єктивно зростає необхідність у підвищенні наукового підходу до комерційного обліку електроенергії [2].

У зв'язку зі значним щорічним зростанням тарифів на електроенергію збільшуються і витрати коштів на $\dddot{1}$ оплату [3], що збільшує актуальність проблеми мінімізації оплати електроспоживання.

Одним із економічних факторів $\epsilon$ можливість купувати електроенергію за різними тарифними системами. Математична модель оцінки ефективності тарифної системи повинна враховувати цей фактор для оцінки електроенергетичних витрат.
\end{abstract}

\section{Аналіз останніх досліджень і публікацій \\ Інформаційні системи все більше застосовуються в задачах ефективного використання електроенергії на залізничному транспорті [4].}

() О.С. Гайденко, 2016
Упровадження автоматизованої системи комерційного обліку електричної енергії на залізницях України дає змогу забезпечити роботу залізниць із закупівлі електроенергії з оптового ринку електричної енергії за диференційованими тарифами й знизити витрати на електроенергію, здійснювати погодинний прогноз споживання електроенергії та керування процесом електроспоживання 3 урахуванням графіка руху поїздів та в подальшому застосовувати регулювання графіка руху 3 метою зниження ціни закупівлі електроенергії [3].

Аналіз досліджень i публікацій показав, що реалізація цього напрямку та розроблення методів i алгоритмів, що дають змогу зменшити плату за електроспоживання на залізничних тягових підстанціях, є актуальним завданням [3-6].

Виділення невирішених раніше частин загальної проблеми

Проблема застосування диференційованих тарифів для залізничного транспорту не може бути вирішена лише застосуванням автоматизованої системи комерційного обліку електричної енергії із відповідним програмним забезпеченням. В умовах суттєвого зростання вартості електроенергії дані 3 автоматизованої системи комерційного обліку електроенергії дають можливість шукати шляхи економії.

Інформаційні технології мінімізації оплати електроспоживання тягових підстанцій поділяються на дві основні групи: які допускають або які не допускають зміни графіка руху поїздів.

Зі зміною графіка руху теоретично можна досягти економічного ефекту на будь-якій електрифікованій ділянці залізниці, проте зміна графіка руху спричиняє додаткові труднощі. Це дослідження присвячене питанню оцінки тарифних систем без зміни графіка руху, що дасть змогу ефективно застосовувати 
вигіднішу тарифну систему без додаткових $B o(t)=k \cdot W(t)$,

матеріальних витрат.

\section{Формування мети}

Метою роботи $\epsilon$ аналіз електроспоживання електрифікованої дільниці залізниці та розроблення комп'ютерно-орієнтованої математичної моделі оцінки ефективності застосування однозонного та тризонного тарифів.

\section{Основний матеріал дослідження \\ Контроль витрати електроенергії здійснюється багатофункціональними електронними лічильниками комп'ютерної системи комерційного обліку, за допомогою якої обсяг закупівлі відстежується погодинно. Аналіз інформації з таких лічильників дає змогу оцінювати потреби споживачів, установити багатотарифні зони оплати [7]. \\ Плата за активну електричну енергію, використану в розрахунковий період $t$ (як правило місяць), за однозонним тарифом визначається за виразом}

де $k$ - ціна згідно з ринковим однозонним тарифом, грн/кВт.год;

$W(t)$ - споживання активної електроенергії, кВт.год.

Споживання електроенергії в енергосистемах протягом дня $\epsilon$ нерівномірним [6]. У часи пікового навантаження на енергосистему постачальники несуть додаткові витрати на генерацію електричної енергії, щоб задовольнити попит. Це пов'язано з тим, що не існуе розвиненої технології накопичення електроенергії у великій кількості.

3 метою вирівняти добовий графік навантаження енергетичної системи України Національна комісія 3 питань регулювання електроенергетики затвердила при розрахунках за електроенергію тарифи, диференційовані за періодами часу. Ставка тарифу для кожного періоду часу визначається шляхом множення встановленого тарифу на відповідний коефіцієнт (табл. 1) [8]. Інформація, вказана в табл. 1, актуальна станом на червень 2016 р. і може змінюватися [9].

Таблиця 1

\section{Тарифні зони та тарифні коефіцієнти тризонного диференційованого тарифу}

\begin{tabular}{|c|c|c|c|c|c|}
\hline \multirow[b]{2}{*}{$\begin{array}{l}\text { Період } \\
\text { часу }\end{array}$} & \multicolumn{3}{|c|}{ Межі тарифних зон, год } & \multirow[b]{2}{*}{$\begin{array}{l}\text { Тривалість } \\
\text { періоду, } \\
\text { год }\end{array}$} & \multirow[b]{2}{*}{$\begin{array}{c}\text { Тарифні } \\
\text { коефіцієнти }\end{array}$} \\
\hline & $\begin{array}{c}\text { січень, лютий, } \\
\text { листопад, } \\
\text { грудень }\end{array}$ & $\begin{array}{c}\text { березень, квітень, } \\
\text { вересень, } \\
\text { жовтень }\end{array}$ & $\begin{array}{c}\text { травень, } \\
\text { червень, липень, } \\
\text { серпень }\end{array}$ & & \\
\hline Нічний & 323 до 6 & 323 до 6 & 324 до 7 & 7 & 0,25 \\
\hline \multirow{3}{*}{$\begin{array}{l}\text { Напів- } \\
\text { піковий }\end{array}$} & 36 до 8 & 36 до 8 & 37 до 8 & \multirow{3}{*}{11} & \multirow{3}{*}{1,02} \\
\hline & 310 до 17 & 310 до 18 & 311 до 20 & & \\
\hline & 321 до 23 & 322 до 23 & 323 до 24 & & \\
\hline \multirow{2}{*}{ Піковий } & З 8 до 10 & З 8 до 10 & 38 до 11 & \multirow{2}{*}{6} & \multirow{2}{*}{1,80} \\
\hline & 317 до 21 & 318 до 22 & 320 до 23 & & \\
\hline
\end{tabular}

Застосування автоматизованої системи комерційного обліку електроенергії дає можливість скористатися диференційованими тарифами (ДТ) на оплату електроенергії й спланувати виробництво таким чином, щоб максимально перевести діяльність енергоємних операцій на час дії пільгових тарифів [2]. Плата за розрахунковий період $t$ при тризонному ДТ становить

$$
B d(t)=A_{H} \cdot k \cdot W_{H}(t)+A_{\mu n} \cdot k \cdot W_{\mu n}(t)+A_{n} \cdot k \cdot W_{n}(t),
$$

де $A_{H}, A_{н n}, A_{n}$ - тарифні коефіцієнти (табл. 1) за електроенергію, спожиту в нічний, напівпіковий i піковий періоди часу відповідно;

$W_{H}, W_{н n}, W_{n}$ - витрати електроенергії за розрахунковий період $t$ у нічний, напівпіковий i піковий періоди часу відповідно, кВтгод.
Прогнозування тягового електроспоживання дає змогу оцінити ефективність застосування ДТ оплати електроенергії. Функції збору та обробки статистичної інформації, необхідної для оцінки та прогнозування електроспоживання, можуть забезпечити пристрої комп'ютерної системи комерційного обліку електроенергії.

Для прийняття рішення про переведення електрифікованої ділянки на ДТ необхідно, щоб задовольнялася умова

$B d^{*}(t)<B o^{*}(t)$

Якщо умову (3) виконано, то переведення лінії на ДТ вигідне. У (3) $B d^{*}(t), B o^{*}(t)$ - прогнозовані значення вартості електроенергії згідно з ДТ та однозонного тарифу відповідно. 
$B d^{*}(t)=k \sum_{j=1}^{i} A_{j} \cdot W_{j}^{*}(t)$,

$B o^{*}(t)=k \cdot W^{*}(t)$,

де $W^{*}(t)$ - прогнозоване значення витрат електроенергії, $i$ - кількість тарифних зон;

$j$ - період часу.

Підставивши (4) в умову (3), отримуємо

$\sum_{j=1}^{i} A_{j} \cdot W_{j}^{*}(t) \leq \sum_{j=1}^{i} W_{j}^{*}(t)$

Рівність умови (5) дає змогу встановити граничні відносні обсяги електроспоживання по зонах ДТ, при яких розглянутий ДТ ефективний за вартістю. Умова (5) може бути застосована як для тризонного ДТ, так i для двозонного.

Для оцінки ефективності переведення тягових підстанцій на ДТ без зміни графіка руху поїздів можна застосовувати правило (5). Для тризонного ДТ воно набуде виду

$W_{H}^{*}(t)-A_{H} \cdot W_{H}^{*}(t)>$

$A_{\text {нn }} \cdot W_{\text {нn }}{ }^{*}(t)+A_{n} \cdot W_{n}^{*}(t)-W_{\text {нn }}^{*}(t)-W_{n}^{*}(t)$.

У випадку справдження виразу (6) різниця між його лівою та правою частинами показує, на скільки економічний виграш від застосування ДТ у нічний період перевищує програш у піковий та напівпіковий періоди. При цьому добуток отриманого значення та ціни електроенергії $k$ буде кількісним показником зекономлених коштів за розрахунковий період.

При розрахунковому періоді тривалістю місяць або рік слід ураховувати, що електроспоживання залізниці залежить від дня тижня та пори року. Це пов'язано зі змінами тривалості світлового дня, температури та графіка руху поїздів. Тому для більш точних обчислень при таких розрахункових періодах умова (5) набуде виду

$\sum_{m=1}^{d}\left(\sum_{j=1}^{i} A_{j} \cdot W_{j}^{*}(t)\right) \leq \sum_{m=1}^{d}\left(\sum_{j=1}^{i} W_{j}^{*}(t)\right)$,

де $d$ - кількість діб у розрахунковому періоді.

Складність обчислень та потреба у великій кількості статистичних даних, які на практиці повинні отримуватися за допомогою комп'ютерної системи комерційного обліку, потребують для розрахунку (7) застосування автоматичних обчислень за допомогою комп'ютерної техніки. Тому приклад розрахунків буде наведено для періоду $t$ одна доба листопада. Взяті для прикладу значення електроспоживання на тягу дільницею наведені в табл. 2.

Таблиця 2

Електроспоживання протягом доби

\begin{tabular}{|c|c|c|c|}
\hline $\begin{array}{c}\text { Час доби, } \\
\text { год }\end{array}$ & $\begin{array}{c}W^{*}(t), \\
\text { кВт }\end{array}$ & $\begin{array}{c}\text { Час доби, } \\
\text { год }\end{array}$ & $\begin{array}{c}W^{*}(t), \\
\text { кВт }\end{array}$ \\
\hline $0-1$ & 0,086 & $12-13$ & 0,07 \\
\hline $1-2$ & 0,119 & $13-14$ & 0,082 \\
\hline $2-3$ & 0,11 & $14-15$ & 0,09 \\
\hline $3-4$ & 0,126 & $15-16$ & 0,061 \\
\hline $4-5$ & 0,119 & $16-17$ & 0,097 \\
\hline $5-6$ & 0,199 & $17-18$ & 0,134 \\
\hline $6-7$ & 0,22 & $18-19$ & 0,199 \\
\hline $7-8$ & 0,265 & $19-20$ & 0,239 \\
\hline $8-9$ & 0,217 & $20-21$ & 0,189 \\
\hline $9-10$ & 0,136 & $21-22$ & 0,139 \\
\hline $10-11$ & 0,101 & $22-23$ & 0,145 \\
\hline $11-12$ & 0,084 & $23-0$ & 0,141 \\
\hline
\end{tabular}

Розрахунок не підтвердив справдження умови (5) для значень електроспоживання табл. 2. У цьому випадку однозонний тариф виявився ефективнішим за тризонний на $7 \%$. Такий результат очікуваний, адже взяті для прикладу вихідні дані були для дільниці, де графік руху поїздів не був підготовлений до застосування ДТ.

Як видно 3 рис. 1, програш 3 плати за електроенергію згідно з тризонним ДТ відбувається 38 по 10 та з 17 по 21 год, тобто під час пікового періоду.

Споживання електроенергії в основному обумовлюється обсягами перевезень [3]. Тому на практиці часто застосування ДТ, як i у випадку прикладу, потребує зміни графіка руху поїздів, причому слід досягти, щоб найвищі значення кривої $\mathrm{W}(\mathrm{t})$ (рис. 2) мали менше збігів із найвищими значеннями кривої $\mathrm{A}(\mathrm{t})$, а, навпаки, знаходилися в місцях іiі мінімуму, тобто перенести навантаження на мережу з пікового періоду пріоритетно в нічний або в напівпіковий.

\section{Висновки}

1. Проведені дослідження споживання електроенергії електрифікованої ділянки показали, що не для всіх випадків застосування тризонного диференційованого тарифу вигідне без зміни графіка руху поїздів. Очевидно, що зміна графіка руху поїздів для застосування тризонного диференційованого тарифу має великий потенціал мінімізації оплати електроспоживання. 


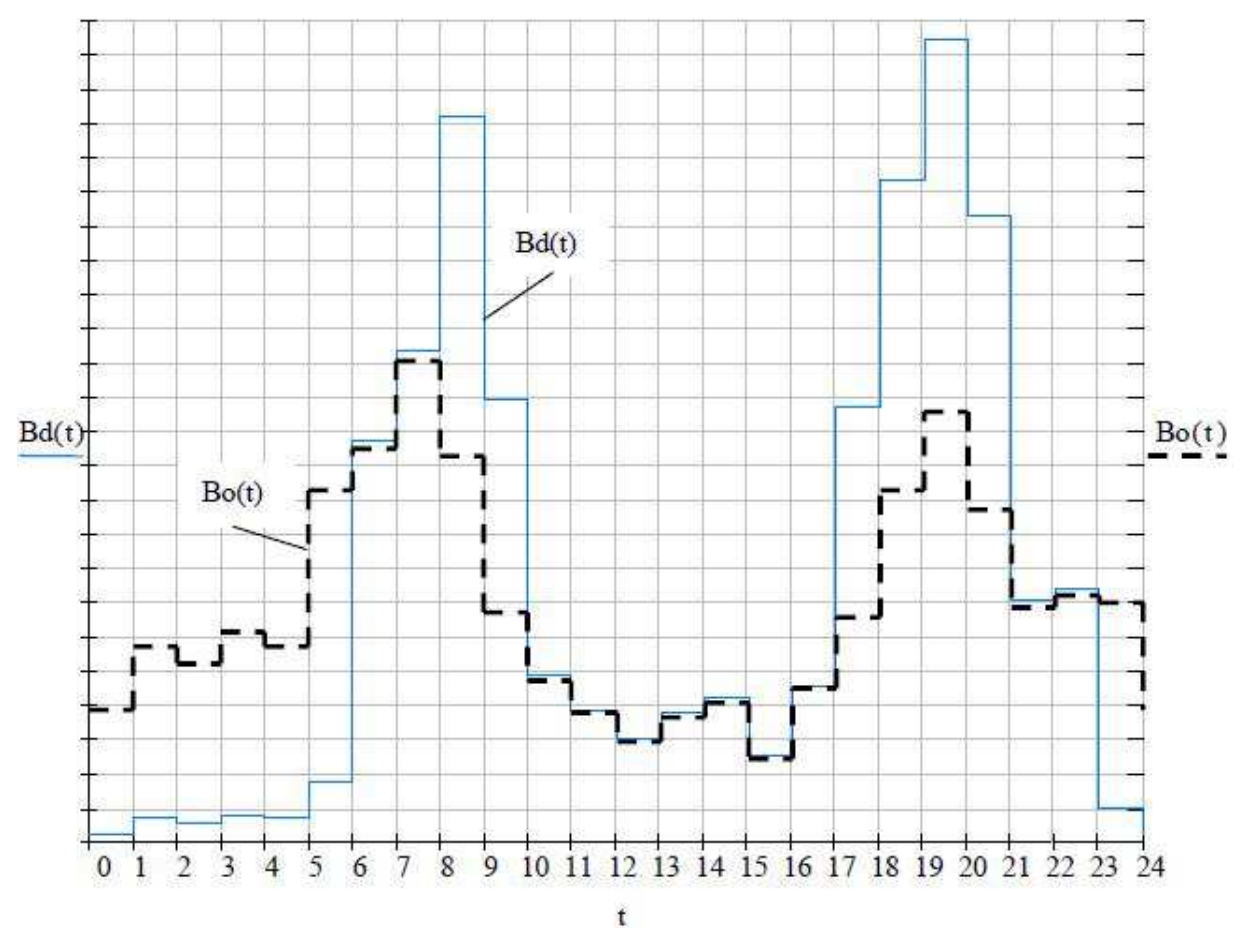

Рис. 1. Плата за спожиту електроенергію протягом доби за однозонним тарифом Во(t) i тризонним ДТ $\mathrm{Bd}(\mathrm{t})$

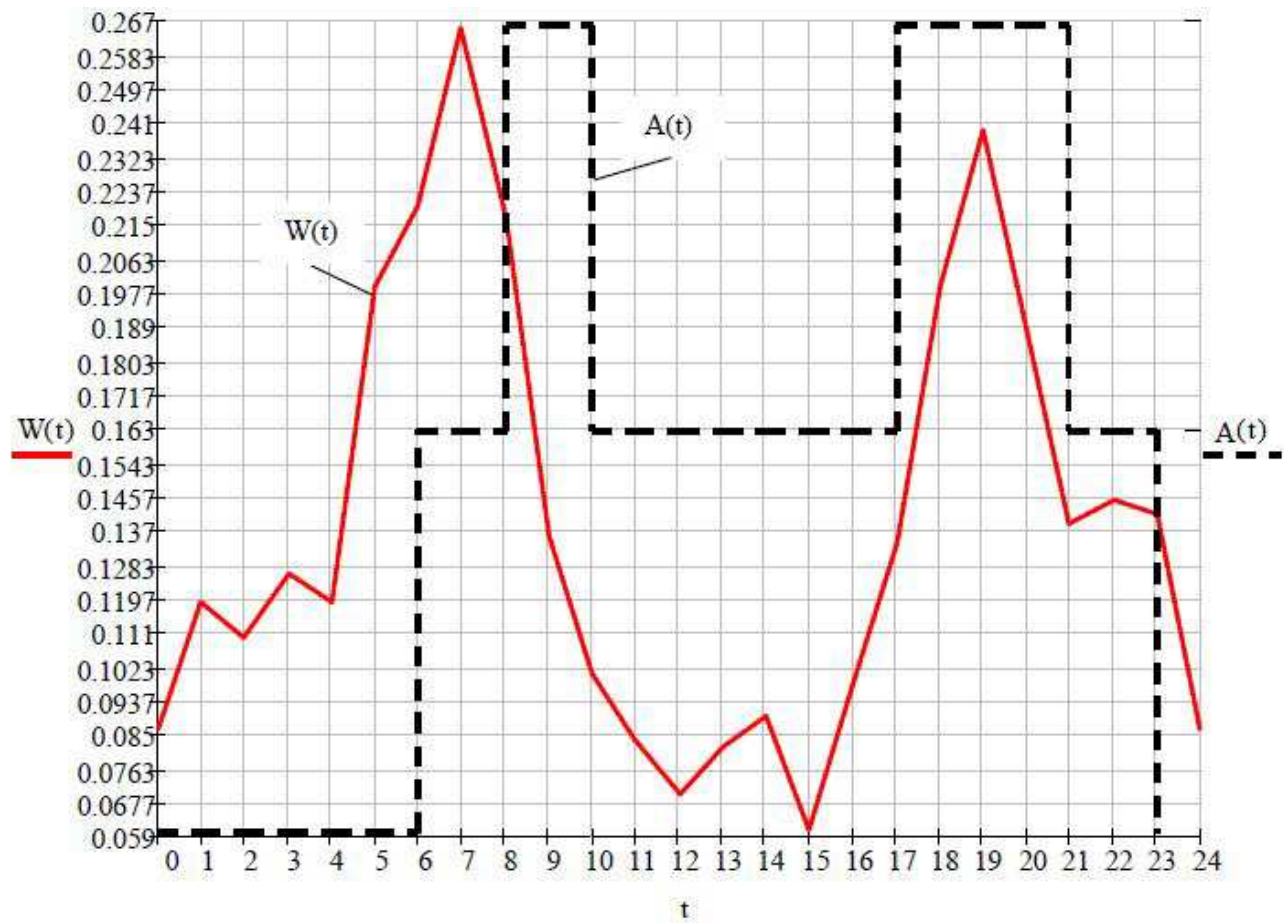

Рис. 2. Залежність споживання електроенергії на тягу W(t), кВт, та вартості електроенергії за тризонним ДТ А(t) від часу доби

2. Розроблена математична модель дає змогу оцінити ефективність застосування однозонного, двозонного та тризонного тарифів оплати електроенергії, розраховувати витрати на закупівлю електроенергії на тягу за періодам часу та граничні обсяги споживання електроенергії в заданих періодах, при яких перехід на закупівлю електроенергії за тризонним диференційованим тарифом економічно 
вигідний. Особливість цієї математичної моделі полягає в тому, що оцінка ефективності застосування тарифу не залежить від ринкової ціни на електроенергію, а лише від обсягів споживання протягом кожного 3 періодів часу диференційованого тарифу.

\section{Література}

1. Максимець, С.М. Діяльність залізниць як учасників оптового ринку електроенергії України [Текст] / С.М. Максимець, А.Л. Лагута // Електрифікація транспорту. - 2011. - № 2. С. $54-58$.

2. Проскурняк, К.І. Дослідження методів синтезу комп'ютерних систем обліку електроенергії за диференційованими тарифами залізниці [Текст] / K.I. Проскурняк // Зб. тез наук.-практ. конф. «Розвиток науки i техніки на залізничному транспорті». - К.: ДЕТУТ, 2014. - С. 67 - 69.

3. Споживання електроенергії та енергозбереження на залізничному транспорті України [Текст] / I.В. Малишко, Л.І. Малишко, Л.В. Пилипенко, В.І. Романко // Вісник ДНУЗТ імені академіка В. Лазаряна. - 2006. - Вип. 12. - С. 245 - 248.

4. Закарюкин, В.П. Сложнонесимметричные режимы электрических систем [Текст] / В.П. Закарюкин, А.В. Крюков. - Иркутск: Иркут. ун-т, 2005. - 273 с.

5. Меламед, А.М. Моделирование динамики изменений потребления электроэнергии энергосистем при неполной информации [Текст] / А.М. Меламед, В.Ф. Тимченко, К.А. Сааред // Электричество. - 1977. - №9. - С. 66 - 69.

6. Стасюк, О.I. Математичні моделі i методи комп'ютерної інтелектуалізації швидкоплинних технологічних процесів електропостачання залізниць [Текст] / О.І. Стасюк , А.Л. Железняк, Л.Л. Гончарова - К.: ДЕТУТ, 2015. - 192 с.

7. Еволюція інтелектуальних електричних мереж та їхні перспективи н в Україні [Текст] / Б.С. Стогній, О.В. Кириленко, А.В. Праховник, С.П. Денисюк // Технічна електродинаміка. - 2012. - № 5 C. $52-67$.

8. Тарифи на електроенергію для юридичних споживачів [Електронний ресурс]. - Режим доступу: http://www.energo.uz.ua/index.php?id=27

9. Постанова НКРЕ від 22.01.2015 № 37 «Про внесення зміни до постанови НКРЕ від 20 грудня 2001 року № 1241 »

Гайденко О.С. Компьютерно-ориентированная математическая модель оценки эффективности тарифной системы оплаты за потребленную электроэнергию железной дорогой. Проведен анализ потребления электроэнергии на тягу железной дороги для оценки эффективности применения дифференцированных тарифов через применение математической модели. Предложено использовать математическую модель для определения эффективности применения дифференцированных тарифов оплаты электроэнергии.

Ключевые слова: модель, электропотребление, компьютерная система коммерческого учета, информационные технологии, минимизация оплаты, стоимость.

O.S. Haidenko. Mathematical model assess the effectiveness of the payment tariff system for electricity consumed by railways for use on a computer. Market conditions and, in particular, the possibility of paying electricity for the various tariffs allow railroad as a large consumer significantly save costs by using the optimal tariff system for each railroad's electrified areas. The research of issue tariff assessment in the current circumstances, with no capacity changes, which will apply more advantageous tariff system without additional material expenses, is devoted. The mathematical model of assess use's effectiveness of the differentiated tariffs electricity payment is developed. The analysis of electric energy consumption for railway traction needs is performed and, for example, the use of a mathematical model at specific conditions is shown. The analysis of electric energy consumption by electrified railway area has found, that using of differentiated three-zone tariff is not advantageous for all cases without changing schedule of the trains traffic. Using of developed mathematical model to determine the effectiveness of application differentiated tariffs electricity payment is suggested.

Key words: model, electric power supply, computer system of commercial accounting, information technology, payment minimization, cost.

Рецензент д.т.н., професор Мараховський Л.Ф. (ДЕТУТ)

Надійшла 16.06.2016 p.

Гайденко О.С., аспірант кафедри «Автоматизація та комп'ютерно-інтегровані технології транспорту», Державний економіко-технологічний університет транспорту, Kиї, $\quad$ Україна. E-mail: haidenko121@gmail.com

O.S. Haidenko, postgraduate of department «Automation and Computer-Integrated Technologies of Transport department», State University for Transport Economy and Technologies, Kyiv, Ukraine. E-mail: haidenko121@gmail.com 